\title{
Plavica Epithermal Au-Ag-Cu Deposit in Eastern Macedonia: Geology and 3D Model of Valuable Component Distribution in Ore
}

\author{
T. Serafimovski ${ }^{a}$, A. V. Volkov ${ }^{b}$ *, D. Serafimovski ${ }^{a}$, \\ G. Tasev ${ }^{a}$, I. Ivanovskic ${ }^{c}$ and K. Yu. Murashov ${ }^{b}$ \\ ${ }^{a}$ Mining and Geological Faculty, Gotse Delchev Univertsity 2000, Stip, Republic of Macedonia \\ ${ }^{b}$ Institute of Geology of Ore Deposits, Petrography, Mineralogy, and Geochemistry, \\ Russian Academy of Sciences, Moscow, 119017 Russia \\ ${ }^{c}$ Genesis Resources International Ltd., DOOEL, Scopje, Republic of Macedonia \\ *e-mail:tma2105@mail.ru \\ Received January 11, 2016
}

\begin{abstract}
The Plavica $\mathrm{Au}-\mathrm{Ag}-\mathrm{Cu}$ deposit is related to the large Neogene volcanic center, which complicates the paleocaldera in the central Kratovo-Zletovo ore district of eastern Macedonia. Based on the geology, ore mineralogy, wall-rock alteration, and fluid inclusions, the Plavica deposit has been referred to the epithermal high-sulfidation type. The general 3D model of orebody at this deposit is based on its general geological structure and complex distribution of metal contents. The framework of the 3D model, which has been constructed in the ArcGIS System, comprises 195 exploration boreholes $47295.8 \mathrm{~m}$ in total length. The 3D model allows to a better understanding of distribution of mineralization and supplements the geological data on the deposit.
\end{abstract}

DOI: $10.1134 / \mathrm{S} 1075701517040067$

\section{INTRODUCTION}

The epithertmal Plavica $\mathrm{Au}-\mathrm{Ag}-\mathrm{Cu}$ deposit is situated in Kratovo-Zletovo volcanic field in the northeast of the Republic of Macedonia $60 \mathrm{~km}$ to the east of Skopje, the country's capital (Fig. 1a). The deposit occupies the central part of Plavica Hill $1290 \mathrm{~m}$ in height (Fig. 1b). In historical terms, $\mathrm{Au}$ and $\mathrm{Cu}$ mining in this area of Balkans started in the time of Alexander the Great and continued during the periods of Roman and Ottoman empires.

The last geological exploration of this deposit was carried out in 2011-2014 by the Macedonian Branch of the Australian company Genesis Resources International (GRI). The exploration was accompanied by research by specialists from the Mining and Geological Faculty, Gotse Delchev University. The scientific database collected in the course of these works combines numerous published papers and technical reports. The integration and analysis of information contained therein made it possible to uncover the basic genetic features of the Plavica deposit.

Over the last two decades, geological 3D simulation by computer software has been transformed into a significant discipline in the geosciences, which comprises geological computer science, geophysics, geochemistry, and geology. 3D or 4D simulation tool are frequently used to enhance economic efficiency and reduce the time required to explore mineral resources by visualization, correlation, and interpretation of geological, geophysical, and geochemical data. One of the main objectives of this paper is to improve knowledge on orebody morphology and to supplement geological information on the deposit.

This article continues a series of publications on ore deposits and metallogeny of the Republic of Macedonia (Volkov et al., 2006; Serafimovski et al., 2010, 2013; Stefanova et al., 2015; Spasovski et al., 2015) prepared as a result of longstanding collaboration between the Laboratory of Ore Deposit Geology at the Institute of Geology of Ore Deposits, Petrography, Mineralogy, and Geochemistry, Russian Academy of Sciences, in Moscow and the Department of Mineral Deposits at the Faculty of Natural and Technical Sciences of the Gotse Delchev University in Stip, Republic of Macedonia.

\section{GEOLOGY AND MINERALOGY OF THE PLAVICA DEPOSIT}

As is known (Tomson et al., 1998; Volkov et al., 2010), numerous base-metal deposits were formed in the Serbian-Macedonian metallogenic zone (SMZ), where deformed Paleozoic metamorphic sequences are overlapped by Tertiary volcanic rocks and cut through by comagmatic porphyry intrusions and deep-seated subvolcanic stocks. The $\mathrm{K}-\mathrm{Ar}$ age of this 

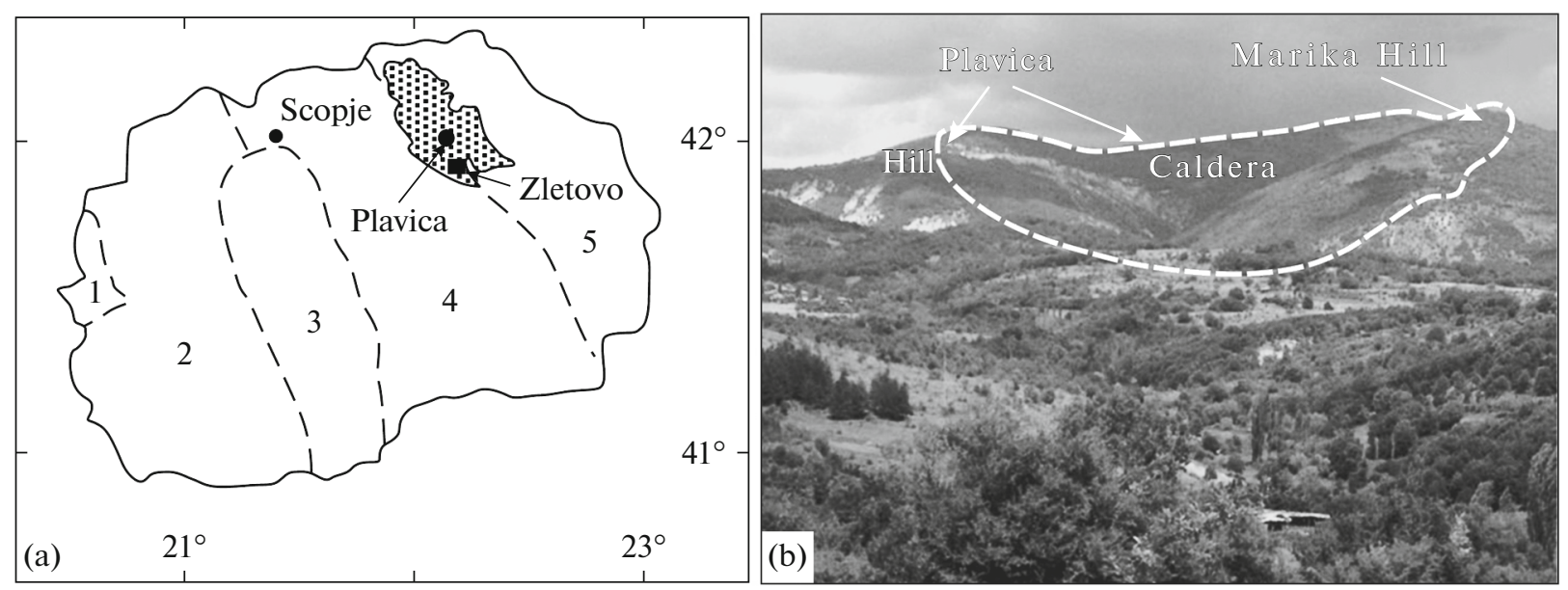

Fig. 1. Location (a) and view (b) of Plavica deposit. Numerals in panel (a) denote tectonic zones and structural units after Dumurdzanov et al. (2005): 1, Pindos; 2, Pelagonian; 3, Pelagonian Antiform; 4, Vardar; 5, Serbian-Macedonian.

igneous complex is $32-16 \mathrm{Ma}$ from late Oligocene to middle Miocene (Karamata et al., 1992). The Tertiary igneous rocks of the SMZ are commonly represented by high-K and intermediate calc-alkaline granodiorite, quartz monzonite, quartz diorite, andesite, and dacite.

The Kratovo-Zletovo ore district is spatially juxtaposed with volcanic field $\left(1200 \mathrm{~km}^{2}\right)$ at boundary between the Serbian-Macedonian massif and the Vardar ophiolite zone (Dumurdzanov et al., 2005) and characterized by zonal arrangement of various types of base- and noble-metal mineralization (Cifliganec et al., 1997).

The central part of the Kratovo-Zletovo region consists of several volcanic structural units with large bodies of secondary quartzite and related $\mathrm{Au}-\mathrm{Ag}-\mathrm{Cu}$ mineralization. The Plavica deposit is related to the large Neogene volcanic center, which complicates a paleocaldera $6.5 \mathrm{~km}^{2}$ in area. The main feature of this structure is numerous faults radiating relative to its central part. The large Zletovo base-metal $(\mathrm{Zn}, \mathrm{Pb}$, $\mathrm{Ag}$ ) vein deposit is located at the southern closure of the paleocaldera (Fig. 1).

Numerous petrographic studies of host rocks have allowed the authors to establish that ignimbrites, stratified volcanic tuffs of amphibole and amphibole-biotite andesites, and dacite-andesite breccia make up the geological structure of the Plavica deposit; subvolcanic stocks and quartz latite dikes are especially abundant along fault zones. The total thickness of the volcanic sequence is about $1000 \mathrm{~m}$. The age of volcanic rocks at the deposit is $26.5 \pm 2 \mathrm{Ma}$ (Serafimovski, 1993).

The petrographic identification of host rocks is hampered by intense hydrothermal alterations, e.g., kaolinization, silicification, alunitization, sericitization, etc. Lava flows and massive tuffs varying in composition from andesite to latite occur in the basal part of the volcanic sequence and are overlain by a series of intercalating tuff flows and volcanic and clastic rocks. The volcanic rocks are intersected by thin nearly vertical bodies of cavernous (vuggy) secondary quartzite $100-150 \mathrm{~m}$ in extent. In the present-day topography, they occupy heights as a result of erosion and topographic inversion (Fig. 2).

As is shown by detailed geological mapping (Serafimovski et al., 2014), dacite and andesite ignimbrites are exposed on the northeastern slopes and also crop out as a wide tract on the southern slope of Mt. Plavica, where numerous $\mathrm{Pb}-\mathrm{Zn}$ ore veins are localized. Volcanic-sedimentary rocks (stratified tuffs) are widespread on the northern slopes. Stratified tuffs are hydrothermally altered along faults and fracture zones. Propylites after dacite and andesite have been revealed on the northern slope of Mt. Plavica and in the southern part of Marika Ridge. Quartz latite has been established in several localities (Karach, Dogandzhinski Kamen, Plavica Potok) at the northern foot of Mt. Plavica, where this rock occurs as necks, stocks, and dikes, which cut through host dacitic and andesitic lavas and tuffs.

A series of inner to outer zones of hydrothermal alteration is represented by monoquartzitic, silicified, alunitic, sericitized, argillic, and propylitic host rocks. With distance from the center of the system, areal alteration gives way to narrow linear zones along fractures that host base-metal veins.

Secondary quartzite is widespread in the central part of the deposit at the top of Mt. Plavica, where the extended northern and southern zones are traced as rocky outcrops. In the eastern part, secondary quartzite is enriched in alunite and gradually transforms into alunite quartzite. Secondary quartzite contains native gold $(0.1-3.0 \mathrm{gpt})$ and an insignificant amount of sulfides. As has been shown by drilling, carrot-shaped quartzite bodies pinch out at a depth of $400 \mathrm{~m}$ from 


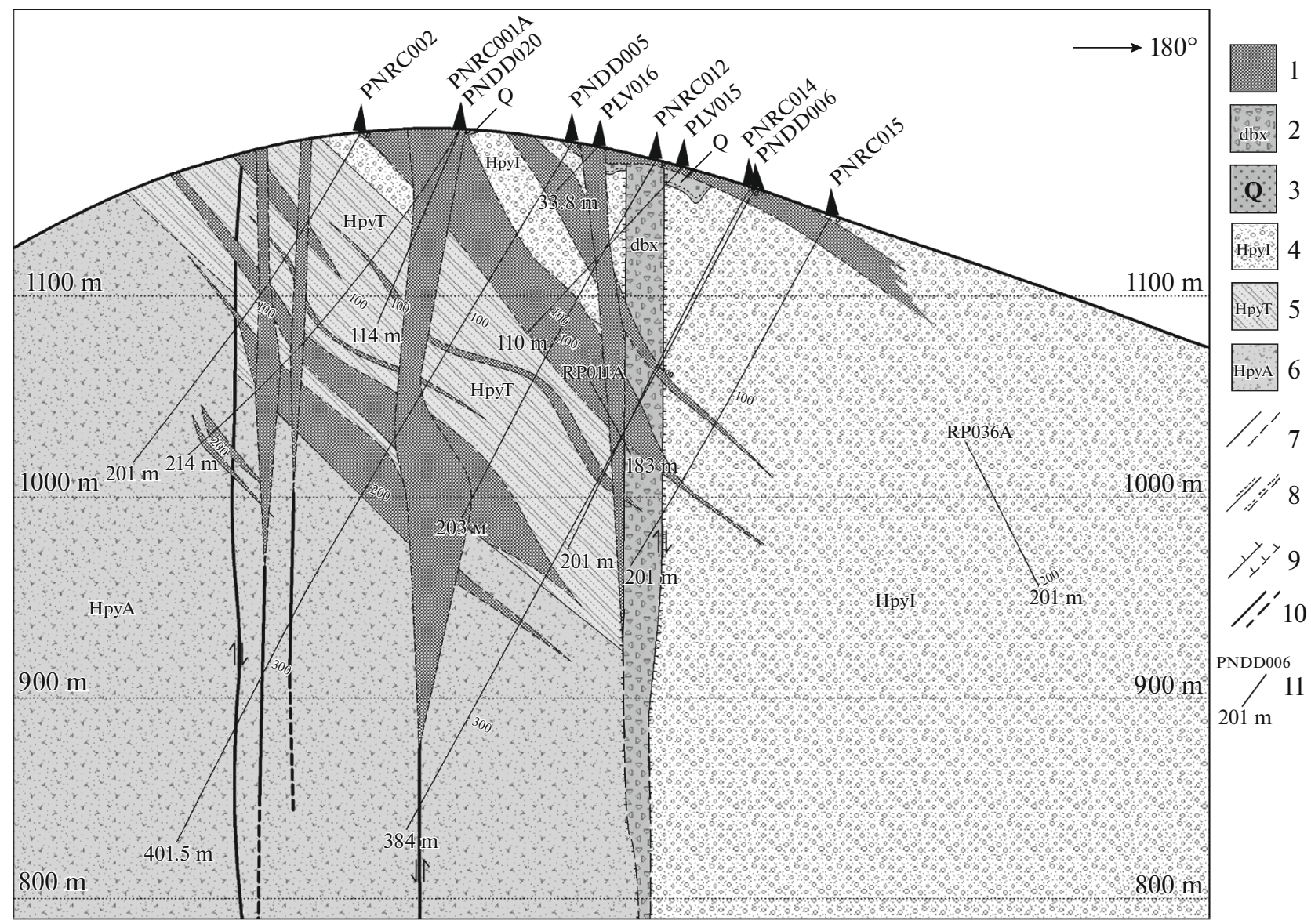

Fig. 2. Geological section across Plavica deposit. Modified after Genesis Resources International Ltd. (1) orebody ( $>0.4$ gpt Au); (2) hydrothermal breccia; (3) hydrothermal quartzite; (4) propylite with sulfide disseminations after tuff; (5) propylite with sulfide disseminations after stratified tuff; (6) propylite with pyrite after andesite and dacite; (7) geological boundaries: observable and inferred; (8) gradual lithologic contacts: observable and inferred; (9) boundary of intruding volcanic rocks; (10) faults: observable and inferred; (11) prospecting and exploration boreholes.

surface. Quartzite commonly contains $97-98$ wt \% $\mathrm{SiO}_{2}$ and consists of amorphous and microcrystalline silicic mass and opal. Tourmaline, pyrophyllite, diaspore, and adularia are identified locally. Disseminated and stringer-disseminated ores are established in silicification, sericitization, and alunitization zones. Judging from the results of structural drilling, the apparent vertical interval of mineralization extends for more than $1000 \mathrm{~m}$. A structural borehole $900 \mathrm{~m}$ deep does not beyond the ore.

In recent years, detailed geological exploration has mainly been carried out in the northeastern part of the deposit, known as Plavica-Zlatica, and at the summit of Mt. Plavica, where secondary quartzite is abundant (Fig. 2). According to the results of these works, $\mathrm{Au}-$ $\mathrm{Ag}-\mathrm{Cu}$ mineralization has been established in elongated lenticular lodes dipping at angles of $30^{\circ}-45^{\circ}$ (Fig. 2) in addition to the carrot-shaped quartzite bodies.

In 2012, GRI estimated the resources of the Plavica deposit as $58 \mathrm{t}$ Au with an average Au grade of $1.0 \mathrm{gpt}$,
$877 \mathrm{t} \mathrm{Ag}$ with an average Ag grade of $25 \mathrm{gpt}$, and $33900 \mathrm{t}$ $\mathrm{Cu}$ with an average $\mathrm{Cu}$ grade of $0.43 \%$ (Stefanova et al., 2013). In 2013, a new orebody (46 m $\times 1.59 \mathrm{gpt}$ $\mathrm{Au}$ ) was intersected by aborehole at the Marika Hill site $800 \mathrm{~m}$ south of the Plavica deposit (Fig. 1b).

The phase composition of ore from the Plavica deposit has been studied since its discovery (Ivanov and Denkovski, 1978; Serafimovski, 1993; Serafimovski and Rakic, 1998, 1999; Alderton and Serafimovski, 2007; Stefanova et al., 2013; Serafimovski and Tasev, 2013; Zlatkov et al., 2014). By now, the following ore minerals have been identified: pyrite, pyrrhotite, chalcopyrite, magnetite, rutile, scheelite, hematite, molybdenite, galena, sphalerite, bornite, enargite, native gold, melnikovite, tetrahedrite, tennantite, chalcocite, digenite, covellite, proustite, native copper, malachite, lazurite, zeligmannite, luzonite, famatinite, petzite, bogdanovite, bezsmertnovite, silvanite, pearceite, bilibinskite, etc. (Serafimovki and Tasev, 2013). The occurrence of sulfosalts (enargite, luzonite) (White et al., 1995), minerals of tennantite-tetrahe- 


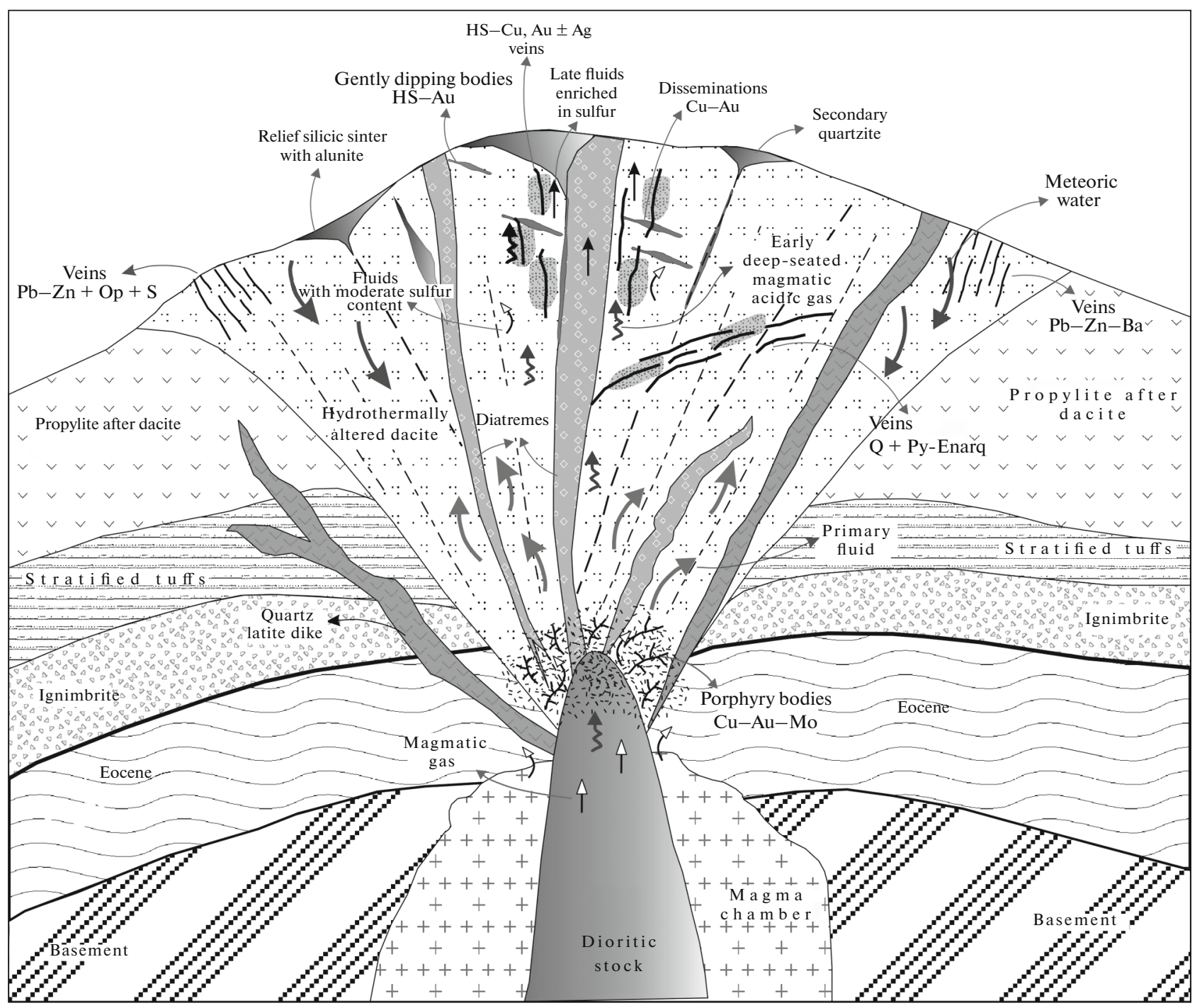

Fig. 3. Schematic genetic model of Plavica $\mathrm{Au}-\mathrm{Cu}$ deposit. HS, fluids enriched in sulfur; Q, quartz; Py, pyrite; Enarg, enargite; Op, opal.

drite series (Baron and Skinner, 1967), the structure of secondary quartzite, and other attributes have made it possible to classify the Plavica deposit as a highly sulfidated epithermal object (Alderton and Serafimovski, 2007). In addition, the most abundant copper sulfides in the ore of the Plavica deposit make up consecutive series: bornite $\rightarrow$ digenite $\rightarrow$ chalcocite $\rightarrow$ covellite nanosegregations (Zlatkov et al., 2014) typical of highlt sulfidated mineralization.

Four morphological mineralization types (Fig. 3) are known at the Plavica deposit: (i) stockwork and $\mathrm{Au}-\mathrm{Cu}$ plus Mo and $\mathrm{Ag}$ disseminations in the central and deepest part of the deposit; (ii) quartz-pyritesphalerite-enargite \pm native gold veins at intermediate levels likely superposed on the stockwork (Fig. 3); (iii) carrot-shaped vertical quartzite bodies at the margin of the central ore zone (Fig. 2); (iv) small veins enriched in $\mathrm{Pb}$ and $\mathrm{Zn}$ up to $1 \%$ in total, which are similar to the large and thick $\mathrm{Pb}-\mathrm{Zn}$ veins mined at the neighboring Zletovo Mine.

\section{GENETIC FEATURES OF THE DEPOSIT}

The highest gold concentrations at the Plavica deposit are related to bodies of secondary quartzite. Orebodies of this type have been established at many highly sulfidated epithermal deposits worldwide (Sillitoe and Hedenquist, 2003). Thus, the Plavica orebodies are close in morphology and composition to orebodies at the Summitville deposit in Colorado, United States (Stoffregen, 1987). Another feature of these deposits is widespread argillic alteration, which indicates a low $\mathrm{pH}$ of fluid and intense acidic leaching (Fig. 3). Sericitic alteration is also known at the Plavica deposit, but only at a great depth in its central part (Fig. 3). 
The thick zone of argillic alteration and massive secondary quartzite bodies, which surround deep zone of sericitization at the Plavica deposit, make it possible to suggest that its origin is close to that of the Rodalcular deposit in Spain, where hydrothermal fluids, when cooling, became more acidic due to incorporation of dissociated magmatic $\mathrm{SO}_{2}$ and continued to ascend (Arribas, 1995).

Highly sulfidated mineralization is frequently related to the upper parts of porphyry copper deposits; the Lepanto deposit in the Philippines is a well-known example. Fluids in such systems are highly saline and enriched in $\mathrm{CO}_{2}$ (Hedenquist et al., 1998). The data on fluid inclusions in quartz from ore at the Plavica deposit also provide evidence for the participation of highly saline magmatic fluid in ore formation (Alderton and Serafimovski, 2007).

Exploration boreholes have opened porphyry copper mineralization hosted in sericitic metasomatic rocks at deep levels of the Plavica deposit. The geophysical data suggest that a porphyry stock occurs at the base of the volcanic sequence (Serafimovski et al., 2014). Thus, the hypothesis that the Plavica deposit is the upper part of a porphyry copper system apparently corresponds to reality (Fig. 3).

As follows from the schematic model of the Plavica deposit (Fig. 3), the structural and lithologic settings ensure delivery of fluids from magma chambers via zones of crushing, brecciation, intense faulting, and fracturing up to subvolcanic and volcanic levels, where highly sulfidated epithermal $\mathrm{Au}-\mathrm{Cu}$ disseminated mineralization of the near-surface type forms in cavernous secondary quartzite. In addition, the model shows that the copper and base-metal veins occupy certain hypsometric levels depending on evolution of ore formation.

The validity of the suggested model is confirmed by the disposition of various types of mineralization in the Kratovo-Zletovo ore district (Serafimovski et al., 2014).

\section{D MODELING TECHNIQUE}

At present, various specialized software, e.g., DATAMINE, MICROMINE, VOXLER, Rock Works, SURPAC VISION, etc., is actively used in geological exploration and mining at various ore deposits. As a rule, these software packages consist of different program modules: estimation of resources, statistic analysis, designs of open pits and underground workings, drill-and-fire systems, etc. (Petrov et al., 2015). The modules consist of GIS algorithms based on information obtained in the course of geological, geophysical, mineralogical, and other research. It should be noted that these software tools have become widespread owing to possibility of coordinating, mathematically processing, and interpreting the results in a $3 \mathrm{D}$ environment. The requirements on completeness and accuracy of GIS information input increase in connection with the complexity of the models representing ore-forming fluid-magmatic systems. 3D modeling calls for large robust computing systems, because integration of various informational media is realized in the visual 3D model and computation is performed in three coordinates, $X, Y$, and $Z$.

The Target 3D program module developed for the traget ArcGIS system was used to create the 3D model, which reproduces the $\mathrm{Au}$ and $\mathrm{Cu}$ distribution in the orebody of the Plavica deposit. This module makes it possible to display borehole, surface, and other types of data within an interactive 3D environment at their true 3D location (Ivanovski et al., 2015). The ArcGIS system is widely used by Australian geological exploration companies for 3D simulation. One important advantage of this system is the relatively low cost as compared with other software.

GRI placed the database at our disposal for 3D simulation of the Plavica deposit. The database contains information on 195 boreholes reaching a depth of $594.1 \mathrm{~m}$. The area of geological exploration was $0.63 \mathrm{~km}^{2}$. The boreholes were arranged according to a $50 \times 100 \mathrm{~m}$ survey grid and sampled at meter intervals. The database contains 43965 multielemental AAS analyses for $\mathrm{Au}, \mathrm{Ag}, \mathrm{Cu}, \mathrm{Zn}, \mathrm{Pb}$, and $\mathrm{AES}$ analyses for 36 elements of cores and cuttings. In addition, the database contains information on GPS coordinates, depth, and orientation of holes, lithology, and mineralogy.

The framework of the 3D model of the Plavica deposit comprises 195 exploration boreholes $47295.8 \mathrm{~m}$ in total length. Seventy-four of them are diamond core drilling holes $23908.3 \mathrm{~m}$ in total length and $400 \mathrm{~m}$ in average depth. The rest are 121 reversed backwashing drilling holes $23387.5 \mathrm{~m}$ in total length and $200 \mathrm{~m}$ in average depth. The holes vary in azimuth and depth, but most have an azimuth of $360^{\circ}$ and at dip angle of $60^{\circ}$. The gold and copper contents obtained by boreholes in certain mineralized zones are the basis for 3D constructions. Barren holes were also incorporated into the framework, in order to get a more representative $3 \mathrm{D}$ model.

The holes, their openings, and 3D projections are displayed by 3D models in their true coordinates. The 3D bodies constructed from drilling sections are shown immediately in the 3D viewing window in their real orientation using Geosoft on-the-fly technology. Other images, including raster ones, can be readily placed in any given orthogonal plane. $3 \mathrm{D}$ bodies with variable boundary values are displayed by means of the Target 3D Tool.

The distribution of element contents in the 3D model has been obtained by the common kriging method (Matheron, 1971), which is based on estimation of moving average value of data, which satisfies various forms of dispersion (Goovaerts, 1997). Kriging is frequently used to assess mineral resources (Chile's and Delfiner, 1999). 


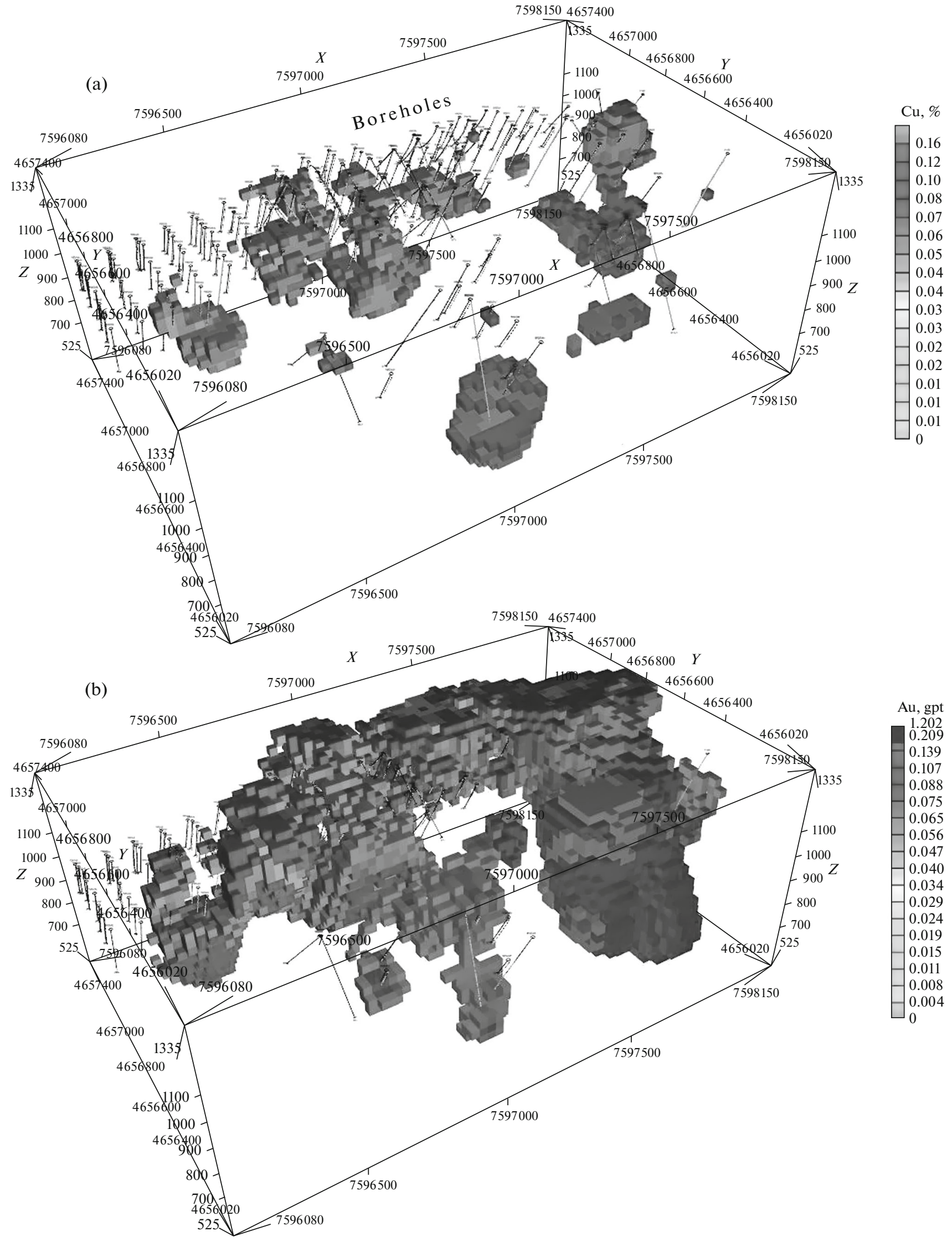

Fig. 4. 3D model of Plavica deposit, resolution is $30 \mathrm{~m}$ : (a) $\mathrm{Cu}$ and (b) Au mineralization. 


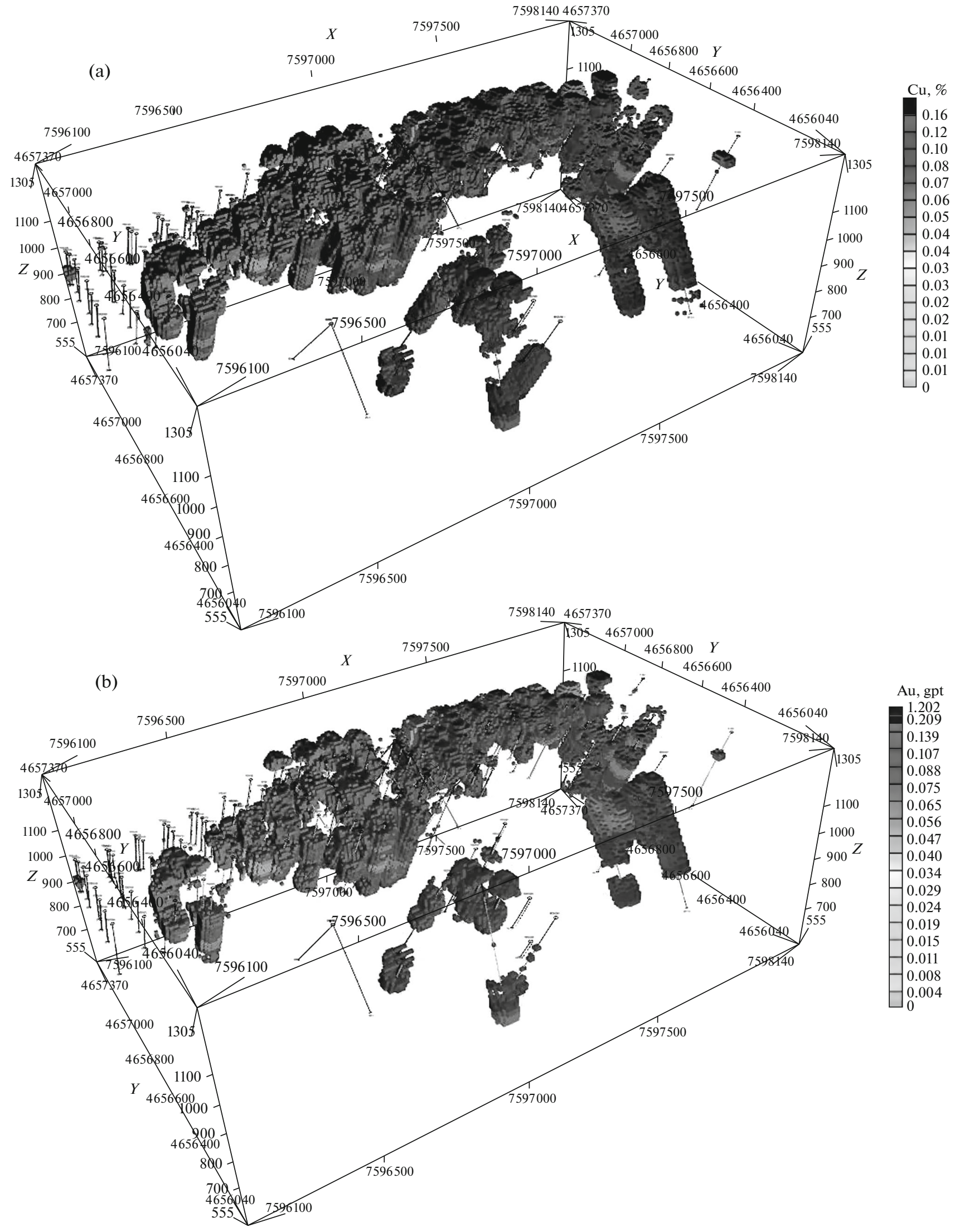

Fig. 5. 3D model of Plavica deposit, 10 m resolution: (a) $\mathrm{Cu}$ and (b) Au mineralization. 


\section{DISCUSSION}

The 3D model was constructed taking into account fault zones, the general geological structure, and complex distribution of metal contents at the Plavica deposit (Figs. 4, 5). The model incorporates all available data and information in analogy with integrated models of other deposits (Arvanitidis et al., 2013). The characteristics of the 3D model make it possible to determine not only ore volume, but also the loss of a mineralized system, as was assumed for the Kristineberg District in Sweden (Chmielovski et al., 2013) and the Gerakario and Kadiica areas in Greece and Macedonia, respectively (Christidis et al., 2014).

Simulation has shown that even a relatively small detailing of volumetric calculations (from $30 \times 30 \mathrm{~m}$ to $10 \times 10 \mathrm{~m}$ ) refines the volume of the entire mineralized zone for both $\mathrm{Au}$ and $\mathrm{Cu}$ (Figs. 4a, 4b, 5a, 5b). The significant correlation between $\mathrm{Cu}$ and $\mathrm{Au}$ at a resolution of $30 \mathrm{~m}$ (Figs. 4a, 4b) makes the increase in detailing to $10 \mathrm{~m}$ more evident and logical (Figs. 5a, $5 b)$. In addition, the contours of the orebody for both $\mathrm{Au}$ and $\mathrm{Cu}$ at a detailed resolution show a stable correlation with the fault systems (Fig. 2) and thus reflect their spatial position.

\section{CONCLUSIONS}

The following geological results have been obtained in the course of simulation: (i) the contour of mineralization expanded to a depth of $300 \mathrm{~m}$; (ii) additional nearly meridional through faults have been established (Figs. 4, 5); (iii) further study will allow researchers to refine the metallogenic and ore-controlling significance of these faults; (iv) the 3D model distinctly shows the isometric and lenticular morphology of $\mathrm{Au}-\mathrm{Cu}$ disseminated mineralization, which changes with depth; (v) the 3D model limits the spatial position of $\mathrm{Au}-\mathrm{Cu}$ mineralization to a depth interval from 1305 to $600 \mathrm{~m}$; this is supported by geochemical sections (Serafimovski et al., 2004).

The results allow us to state that this 3D model will facilitate planning of future geological exploration of the Plavica deposit and will specify its trend.

\section{ACKNOWLEDGMENTS}

We are grateful to the management of Genesis Resources International for their permission to use its software and analytical and geological databases to create the 3D model of the Plavica deposit. This study was supported by project no. 72-5 of the Institute of Geology of Ore Deposits, Petrography, Mineralogy, and Geochemistry, Russian Academy of Sciences "Metallogeny of Unique Ore Districts Various in Age and Located in Volcanic Belts and Orogenic Zones of the Marginal Lithosphere in Northeast Asia.”

\section{REFERENCES}

Alderton, H.M.D. and Serafimovski, T., The geology and genesis of the Plavica copper-gold deposit, Macedonia, Appl. Earth Sci. (Trans. Inst. Min. Metall. B), 2007, vol. 116, no. 2, pp. 94-105.

Arribas, A., Characteristics of high-sulfidation epithermal deposits, and their relation to magmatic fluid, in magmas, fluids, and ore deposits, Thompson, J. F. H., Ed. Mineral. Ass. Can., Short Course Ser., 1995, vol. 23, pp. 419-454.

Arvanitidis, N.D., Michael, C., Christidis, C., et al., Using 3D/4D modelling tools in exploration for epithermal gold potential areas in Eastern Rhodope zone (Western Trace, NE Greece), Mineral Deposit Research for a High-Tech World, Proceedings of 12th SGA Biennial Meeting, 2013, Uppsala: Elanders Sverige AB, 2013, vol. 1, pp. 58-61.

Barton, P.B. and Skinner, B.J., Sulfide mineral stabilities, Geochemistry of Hydrothermal Ore Deposits, Barnes, H.L. Ed., New York: Holt, Rinehart and Winston, 1967, pp. 236-333.

Chile's, J.P. and Delfiner, P., Geostatistics: Modeling Spatial Uncertainty, New York. Ciley, 1999.

Chmielowski, M.R., Jansson, N., Persson, M.F., et al., 3D geochemical modelling of hydrothermal alteration related to 1.89 Ga VHMS-type deposits, Kristineberg area, Skellefte district, Sweden, Mineral Deposit Research for a HighTech World, Proceedings of 12th SGA Biennial Meeting, 2013, Uppsala: Elanders Sverige AB, 2013, vol. 1, pp. 66-69.

Christidis, Ch., Serafimovski, T., Arvanitidis, N., et al., 3D modeling tools jointly applied on Gerakario (Greece) and Kadiica (FYROM Macedonia) porphyry copper mineralisations, Proceedings of the 20th Congress of Carpathian Balkan Geological Association, Spec. Iss., 2014, vol. 1, pp. 355358.

Chifliganec, V., Jankovic, S., and Serafimovski, T., Geotectonic setting and metallogenic characteristics of porphyry copper deposits in the Serbo-Macedonian province, Rom. J. Mineral Deposits, 1997, vol. 78, no. 2, pp. 85-92.

Dumurdzanov, N., Serafimovski, T., and Burchfiel, B.C., Cenozoic tectonics of Macedonia and its relation to the South Balkan extensional regime, Geosphere, 2005, no. 1, pp. 1-22.

Goovaerts, P., Geostatistics for Natural Resources Evaluation, New York, Oxford: Oxford University Press, 1997.

Hedenquist, J.W., Arribas, A.Jr., and Reynolds, T.J., Evolution of an intrusion-centered hydrothermal system: Far Southeast-Lepanto porphyry-epithermal $\mathrm{Cu}-\mathrm{Au}$ deposits, Philippines, Econ. Geol., 1998, vol. 93, pp. 373-404.

Ivanov, T. and Denkovski, G., Geology of the plavica-zlatica deposit, kratovo-zletovo, Proc, p. 9.

Ivanovski, I., Serafimovski, D., Tasev, G., et al., 3D-modelling of the Plavica $\mathrm{Au}-\mathrm{Cu}$ polymetallic deposit, Republicof Macedonia, Geol. Macedonica, 2015, vol. 29, no. 1, pp. 63-74.

Karamata, S., Krstic, B., and Stojanov, R., Terranes from the Adriatic to the Moesian Massif in the Central part of the Balkan Peninsula, Terra Nova, 4, Abstract suppl., 1992. vol. 2, p. 78.

Matheron, G., The Theory of regionalized variables and its applications, Les cahiers du centre de Morphologie matematique de Fontebleau, no. 5, Paris: Ecole Nationale Superieure des Mines de Paris, 1971. 
Petrov, V.A., Veselovskii, A.V., and Murashov, K.Yu. 3D GIS modeling geodynamic objects, Geoinformatika, 2015, no. 3, pp. 32-38.

Serafimovski, T., Structural-Metallogenetic Features of the Lece-Halkidiki Zone. Types of the Mineral Deposits and Distribution, Spec. Iss. Stip: Faculty of Mining and Geology, Geol. Depart., 1993.

Serafimovski, T. and Rakic, S., The secondary quartzites hosting gold mineralization in the Crni Vrv-Plavica volcanic area, Geol. Macedonica, 1998, vol. 12, pp. 9-21.

Serafimovski, T. and Rakic, S., New geochemical data concerning gold related to silification zones in the Plavica volcanic structure, Eastern Macedonia, Mineral Deposits: Processes to Processing, Stanley et al., Ed., Roterdam: Balkema, 1999, pp. 585-588.

Serafimovski, T. and Tasev, G., Ore-Microscopic Study of Samples from the Plavica Deposit, Stip: Department of Mineral deposits, University "Goce Delcev", 2013.

Serafimovski, T., Stefanova, V., and Volkov, A.V., Dwarf copper-gold porphyry deposits of the Buchim-DamjanBorov Dol ore district, republic of Macedonia (FYROM), Geol. Ore Deposits, 2010, vol. 52, no. 3, pp. 179-195.

Serafimovski, T., Volkov, A.V., Boev, B., et al., Ržanovo metamorphosed lateritic $\mathrm{Fe}-\mathrm{Ni}$ deposit, Republic of Macedonia, Geol. Ore Deposits, 2013, vol. 55, no. 5, pp. 383-398.

Serafimovski, T., Aleksandrov, M., Tasev, G., et al., Elaborate of Detailed Geological Study, with Calculation of Geological Ore Reserves, of Copper and Gold in the Plavica, Kratovo Locality, Skopje: Geol. Depart., 2014.

Sillitoe, H.R. and Hedenquist, W.J., Linkages between volcanotectonic settings, ore-fluid compositions, and epithermal precious metal deposits, Soc. Econ. Geol., Sp. Publ., 2003, vol. 10, pp. 315-343.
Spasovski, O., Volkov, A.V., Serafimovski, T., et al., Amphibolite-hosted $\mathrm{Fe}-\mathrm{Ti}$ oxide mineralization of the Mitrashinci Deposit, Eastern Macedonia, Geol. Ore Deposits, 2015, vol. 57, no. 3, pp. 226-235.

Stefanova, V., Volkov, A.V., Serafimovski, T., et al., Native gold from the Plavica epithermal deposit, Republic of Macedonia, Dokl. Earth Sci., 2013, vol. 451, pp. 818-823.

Stefanova V., Volkov A.V., Serafimovski, T., et al., Native gold of the Borovik Ore Field, Republic of Macedonia (FYROM), Geol. Ore Deposits, 2015, vol. 57, no. 2, pp. 133137.

Stoffregen, R., Genesis of acid-sulfate alteration and $\mathrm{Au}-$ $\mathrm{Cu}-\mathrm{Ag}$ mineralization at Summitville, Colorado, Econ. Geol., 1987, vol. 82, pp. 1575-1591.

Tomson, I.N., Serafimovski, T., and Kochneva, N.T., Cenozoic metallogeny of Eastern Macedonia, Geol. Ore Deposits, 1998, vol. 40, no. 3, pp. 175-183.

Volkov, A.V, Stefanova, V., Serafimovski, T., et al., Formation mechanism of dwarfish $\mathrm{Cu}-\mathrm{Au}$ porphyry deposits of Macedonia, Dokl. Earth Sci., 2010, vol. 431, pp. 429-434.

Volkov, A.V., Serafimovski, T., Kochneva, N.T., et al., The Alshar epithermal Au-As-Sb-Tl deposit, Southern Macedonia, Geol. Ore Deposits, 2006, vol. 48, no. 3, pp. 175-192.

White, N.C., Leake, M.J., McCaughey, S.N., et al., Epithermal deposits of the Southwest Pacific, J. Geochem. Explor., 1995, vol. 54, pp. 87-136.

Zlatkov, G., Tasev, G., Stefanova, V., et al., Composition of some major mineral phases from the Plavica epithermal gold deposit, Eastern Macedonia, Geol. Macedonica, 2014, vol. 28 , no. 2 , pp. $149-163$.

Translated by V. Popov 